\title{
Interspecific differences in the bioconcentration of selenite by phytoplankton and their ecological implications
}

\author{
Stephen B. Baines*, Nicholas S. Fisher \\ Marine Sciences Research Center, State University of New York, Stony Brook, New York 11794-5000, USA
}

\begin{abstract}
The concentration of Se in algal cells is a primary determinant of Se tissue contents in higher level consumers. Differences in the ability of algal species to concentrate selenite and variability in ambient selenite concentrations may be important determinants of algal Se contents. We compared uptake of ${ }^{75} \mathrm{Se}$-labeled selenite by 14 algal species at 2 environmentally relevant selenite concentrations. Se content per unit cell volume $\left(\mathrm{Se} / V_{\mathrm{c}}\right.$ ) varied by almost 4 orders of magnitude when algae were exposed to $4.5 \mathrm{nM}$ selenite and almost 5 orders of magnitude when exposed to $0.15 \mathrm{nM}$ selenite. Chlorophytes typically exhibited the lowest Se enrichments, while prymnesiophytes, prasinophytes and dinoflagellates exhibited the highest. The $\mathrm{Se} / V_{\mathrm{c}}$ of diatoms and cryptophytes varied by $>2$ orders of magnitude. Even at the lowest selenite concentration, about half the species concentrated Se to an extent that might cause toxicity at higher trophic levels. Within species, the Se cell concentration typically varied by only 2 - to 3 -fold when exposed to selenite concentrations that differed by 30 -fold. The Se cell concentration of only 1 species, the diatom Skeletonema costatum, varied in proportion to ambient selenite concentrations. A more detailed study of the dependence between Se cell concentration on ambient selenite concentrations in the diatom Thalassiosira pseudonana revealed an asymptotic approach to a maximum Se cell concentration at high ambient selenite concentrations $(>0.1 \mathrm{nM})$. Given the results for other species exposed to 4.5 and $0.15 \mathrm{nM}$ selenite, such saturation is likely to be a common feature. Our results indicate that the composition of the phytoplankton community could have a pronounced impact on Se concentrations in marine food webs.
\end{abstract}

KEY WORDS: Selenium · Algae - Bioaccumulation · San Francisco Bay · Water pollution · Water quality criteria

\section{INTRODUCTION}

Selenium is both an essential nutrient and, at slightly higher concentrations, a toxic contaminant for aquatic organisms (Brown \& Shrift 1982, Lemly 1985, Harrison et al. 1988, Lindstrom 1991). Agricultural, industrial and urban activities have elevated Se concentrations in many aquatic ecosystems (Cutter 1989). In the marine plankton Se is primarily concentrated from the dissolved phase by bacteria and algae (Wrench \& Mea-

*E-mail: sbaines@ms.cc.sunysb.edu sures 1982, Foda et al. 1983, Vandermeulen \& Foda 1988) and is very efficiently assimilated from algae by herbivores (Fisher \& Reinfelder 1991, Luoma et al. 1992, Reinfelder \& Fisher 1994). Greater than $95 \%$ of the Se in benthic filter feeding bivalves is derived from food (Luoma et al. 1992, Wang et al. 1996). Consequently, Se concentrations in phytoplankton are critical determinants of Se concentrations in the tissues of filter feeding aquatic organisms.

Because species of marine phytoplankton vary widely in their ability to take up Se from water (Vandermeulen \& Foda 1988, Riedel et al. 1991, Fisher \& Wente 1993), phytoplankton community composition 
may be an important determinant of the Se concentration in phytoplankton biomass. To date, most assessments of interspecific variability of Se uptake have focused on only a few taxonomic groups or on single species from different groups. Furthermore, these studies have generally measured Se uptake rates rather than Se concentrations in cells. Information on Se cell concentration of diverse algal species is necessary to quantitatively assess the potential impact of phytoplankton species composition on herbivore Se tissue concentrations and Se toxicity.

Another important variable affecting Se contents of phytoplankton is the concentration of selenite (Se(IV)), which is generally the most available form of inorganic Se to marine phytoplankton (Vandermeulen \& Foda 1988, Riedel et al. 1991, Hu et al. 1997). Previous studies relating selenite uptake by marine phytoplankton to selenite concentration have suggested a linear dependence between these 2 variables (Vandermeulen \& Foda 1988, Riedel et al. 1996). However, incorporated selenite is reduced and incorporated covalently into organic selenides, in particular selenocysteine and selenomethionine (Wrench 1978, Bottino et al. 1984, Vandermeulen \& Foda 1988, Besser et al. 1994). Since Michaelis-Menten kinetics should control the accumulation and enzymatic biosynthesis of these Se-containing compounds, the relationship of Se incorporation by algae and ambient selenite concentrations may be non-linear if ambient concentrations approach those needed to saturate enzyme kinetics.

In this paper we compare the effects of selenite concentration and taxonomic differences on Se concentration in phytoplankton. We present data on selenite uptake by 14 species representing 6 algal divisions.
We also consider the implications of our results for assessing Se concentrations of higher trophic level organisms in San Francisco Bay. This estuary has received significant inputs of Se from agricultural runoff, oil refinery wastes, and sewage outflows (Cutter 1989). Studies in the northern region of the bay have demonstrated high Se tissue concentrations in diving ducks and sturgeon, which are attributable to high Se concentrations in the resident bivalve molluscs (Luoma et al. 1992). While our study was designed to address the conditions prevalent in San Francisco Bay, we believe the results are applicable to other estuaries, particularly those with comparable Se concentrations.

\section{MATERIALS AND METHODS}

The 14 species, representing 6 different divisions, used in these experiments are listed in Table 1. Clones consisted largely of coastal and estuarine isolates. Three of them, Skeletonema costatum, Rhodomonas salina and Prorocentrum minimum, are important components of the San Francisco Bay plankton (Lehman 1996). Experiments were conducted in $0.2 \mu \mathrm{m}$ sterile filtered surface seawater (salinity 35) collected $8 \mathrm{~km}$ offshore from Southampton, New York, that was enriched with modified f/2 nutrients (Fisher \& Wente 1993). All cultures were kept at $16^{\circ} \mathrm{C}$ on a $14: 10 \mathrm{~h}$ light:dark cycle. None of the cultures were acclimated to the experimental concentrations of Se prior to the accumulation experiments.

Selenite was added to the cultures as both radioisotope and stable selenite to achieve final concentrations of either 0.15 or $4.5 \mathrm{nM}$. These concentrations encom-

Table 1. Characteristics of the algal species used in the experiments. C contents estimated from cell volume using the equations of Strathmann (1967), as described in text

\begin{tabular}{|c|c|c|c|c|c|c|}
\hline & Species & $\begin{array}{c}\text { Clonal } \\
\text { designation }\end{array}$ & $\begin{array}{c}\text { Spherical } \\
\text { diameter } \\
(\mu \mathrm{m})\end{array}$ & $\begin{array}{c}\text { Cell } \\
\text { volume } \\
\left(\mu \mathrm{m}^{3}\right)\end{array}$ & $\begin{array}{c}\text { Cell } \\
\text { carbon } \\
\left(\text { pg cell }^{-1}\right)\end{array}$ & $\begin{array}{l}\text { Cell carbon } \\
\text { concentration } \\
\left(\text { pg C } \mu^{-3} \text { ) }\right.\end{array}$ \\
\hline \multirow[t]{3}{*}{ Bacillariophyceae } & Chaetoceros gracilis & UTEX LB 2658 & 4.9 & 61.6 & 8.6 & 0.14 \\
\hline & Skeletonema costatum & UTEX LB 2308 & 5.5 & 87.1 & 11.2 & 0.13 \\
\hline & Thalassiosira pseudonana & CCMP 1335 & 4 & 33.5 & 5.4 & 0.16 \\
\hline \multirow[t]{3}{*}{ Chlorophyceae } & Chlorella autotrophica & CCMP 243 & 3.6 & 24.4 & 5.3 & 0.22 \\
\hline & Dunaliella tertiolecta & CCMP 1320 & 6.2 & 124.8 & 21.6 & 0.17 \\
\hline & Nannochloris atomus & CCMP 509 & 3.7 & 26.5 & 5.7 & 0.22 \\
\hline \multirow[t]{3}{*}{ Cryptophyceae } & Chroomonas sp. & UTEX LB 2000 & 3.4 & 20.6 & 4.6 & 0.22 \\
\hline & Cryptomonas sp. & UTEX LB 2423 & 7.3 & 203.7 & 32.8 & 0.16 \\
\hline & Rhodomonas salina & CCMP 1319 & 7 & 179.6 & 29.5 & 0.16 \\
\hline Dinophyceae & Prorocentrum minimum & CCMP 696 & 13 & 1150.3 & 144.6 & 0.13 \\
\hline \multirow[t]{2}{*}{ Prasinophyceae } & Pycnococcus provasolii & CCMP 1203 & 2.7 & 10.3 & 2.6 & 0.25 \\
\hline & Tetraselmis levis & CCMP 896 & 8.2 & 288.7 & 44.3 & 0.15 \\
\hline \multirow[t]{2}{*}{ Prymnesiophyceae } & Emiliania huxleyi & CCMP 375 & 3.7 & 26.5 & 5.7 & 0.22 \\
\hline & Isochrysis galbana & CCMP 1323 & 3.6 & 24.4 & 5.3 & 0.22 \\
\hline
\end{tabular}


pass the range ( 0.2 to $1.0 \mathrm{nM})$ of selenite concentrations observed in the northern reach of San Francisco Bay (Cutter 1989). Se radiolabeled with ${ }^{75} \mathrm{Se}$ was added to the cultures to attain a radioactivity of $90 \mathrm{kBq}$ $\mathrm{l}^{-1}$ or until the selenite concentration equaled the target concentration for the experiment. This amount of radioactivity allowed detection of $0.5 \%$ incorporation of the dissolved selenite with $5 \%$ analytical error using the filtration and counting protocols outlined below. Independent estimates of selenite in the base media using selective Se hydride formation, liquid nitrogen cooled trapping and atomic absorption detection (Cutter 1989) were below detection limits $(<0.02 \mathrm{nM})$. The algae used to inoculate cultures were from log phase cultures. There were triplicate cultures for each combination of species and selenite concentration. The uptake of ${ }^{75} \mathrm{Se}$ selenite followed protocols described elsewhere (Fisher et al. 1983). The amount of Se that was incorporated into the particulate phase was calculated as the net radioactivity measured as counts per minute of ${ }^{75} \mathrm{Se}$ per cell divided by the counting efficiency $(95 \%)$ of the gamma counter and the specific activity of the isotope. Gamma emissions of the samples were determined at $288 \mathrm{keV}$ with a PharmaciaWallac LKB Compugamma counter fitted with a $\mathrm{NaI}(\mathrm{Tl})$ well detector. A Coulter Multisizer II system was used to obtain simultaneous measurements of cell concentrations from $5 \mathrm{ml}$ aliquots.

The Se concentration per unit of cell volume $\left(\mathrm{Se} / V_{\mathrm{c}}\right.$ $\mathrm{ng} \mu \mathrm{m}^{-3}$ ) was determined from regressions of blankcorrected particulate Se concentration (PSe) on total volume of cells per ml of media $\left(V_{\mathrm{c}}\right)$. Typically we fit simple linear models predicting particulate Se from total cell volume. The slopes of these regressions represented our best estimate of Se content $\mu^{-3}$ of cellular material. In some cases uptake of Se leveled off after the total cell volume reached a certain level (see 'Results'). These data fit a rectangular hyperbolic model,

$$
\mathrm{PSe}=y_{0}+\frac{\mathrm{PSe}_{\mathrm{m}} \times V_{\mathrm{c}}}{V_{1 / 2 \mathrm{PSe}}+V_{\mathrm{c}}}
$$

where $V_{\mathrm{c}}$ is the total cell volume $\mathrm{ml}^{-1}, y_{0}$ is an intercept term, $\mathrm{PSe}_{\mathrm{m}}$ is an estimate of the maximum PSe, and $V_{1 / 2 \mathrm{PSe}}$ is the total cell volume at which the PSe is one-half $\mathrm{PSe}_{\mathrm{m}}$. When the term $y_{0}$ was insignificant ( $p>0.1$ ), a model without the intercept term was fit. The slope of the hyperbola at the start of the experiment is $\mathrm{PSe}_{\mathrm{m}} /\left(V_{1 / 2 \mathrm{PSe}}+V_{\mathrm{c} 0}\right)$, where $V_{\mathrm{c} 0}$ is the cell volume at the initiation of the experiment. Because $V_{\mathrm{c} 0}$ was always $<10 \%$ of $V_{1 / 2 \mathrm{PSe}}$ its contribution was ignored. This slope represents the Se $\mu^{-3}$ of cellular material at the initial experimental concentration. The standard error for this estimate of initial Se concentration was calculated as

$$
\sigma_{\mathrm{PSe} / V}=\sqrt{\left(\frac{\sigma_{\mathrm{PSe}}^{2}}{\mathrm{PSe}_{\mathrm{M}}^{2}}+\frac{\sigma_{K_{V}}^{2}}{V_{1 / 2 \mathrm{PSe}}}\right) \cdot\left(\frac{\mathrm{Pse}_{\mathrm{M}}}{V_{1 / 2 \mathrm{PSe}}}\right)^{2}}
$$

where $\sigma_{\mathrm{PSe}}$ and $\sigma_{K_{\mathrm{V}}}$ are the standard deviations for $\mathrm{PSe}_{\mathrm{m}}$ and $V_{1 / 2 \mathrm{PSe}}$, respectively. All regressions were fit in SigmaPlot (vers. 4.1, SPSS) using a Marquart-Levenberg iterative search algorithm. The $\mathrm{C}$ content of the algae was estimated from cell volume based on equations of Strathmann (1967). Separate equations were used for diatoms and for other species. The diatom equation was $\log C\left[\mathrm{pg} \mathrm{cell}{ }^{-1}\right]=-0.42+0.758 \times \log ($ cell volume $\left.\left[\mathrm{mm}^{3} \mathrm{cell}^{-1}\right]\right)$. The equation for the other species was $\log C\left[\mathrm{pg} \mathrm{cell}{ }^{-1}\right]=-0.46+0.856 \times \log ($ cell volume $\left.\left[\mathrm{mm}^{3} \mathrm{cell}^{-1}\right]\right)$.

To determine if the Se concentration of algae exhibited an asymptotic relationship to the concentration of selenite in solution, uptake experiments were conducted over a range of selenite concentrations using the diatom Thalassiosira pseudonana. Protocols outlined above were followed except that selenite was added to achieve concentrations of $0.01,0.1,1.0$ and $10 \mathrm{nM}$. The concentration of Se in algae at the beginning of the experiment was calculated using regressions of PSe on total volume of algal cells according to the models described above. These concentrations were then regressed against the initial concentration of added selenite, again using a rectangular hyperbolic model. In this instance, the asymptote of the regression is the maximum value of $\mathrm{Se} / V_{\mathrm{c}}$, and the half saturation constant refers to the concentration of added selenite. The half saturation constant is biased by an amount equal to the unknown background concentration of selenite $\left(\mathrm{Se}_{\mathrm{u}}\right)$, which was undetectable in our base media.

\section{RESULTS}

Cell growth was generally logarithmic throughout the experiments (Fig. 1). After an initial phase of fast uptake the fraction of $\mathrm{Se}$ in particles also often increased logarithmically (Fig. 2). However, in experiments with species that concentrate selenite very effectively, the fraction of particulate Se often approached an asymptote before cell growth had stopped or the dissolved Se was completely utilized (e.g., Isochrysis galbana, $4.5 \mathrm{nM}$ ). The cessation of selenite uptake by these species caused the amount of Se per cell to decline with time as cells continued to grow (Figs. 3 \& 4). As most clearly exemplified by Thalassiosira pseudonana, species that exhibited this pattern tended to leave approximately the same fraction (but different absolute concentrations) of Se in solution regardless of the initial selenite concentration (Figs. 3 \& 4). 


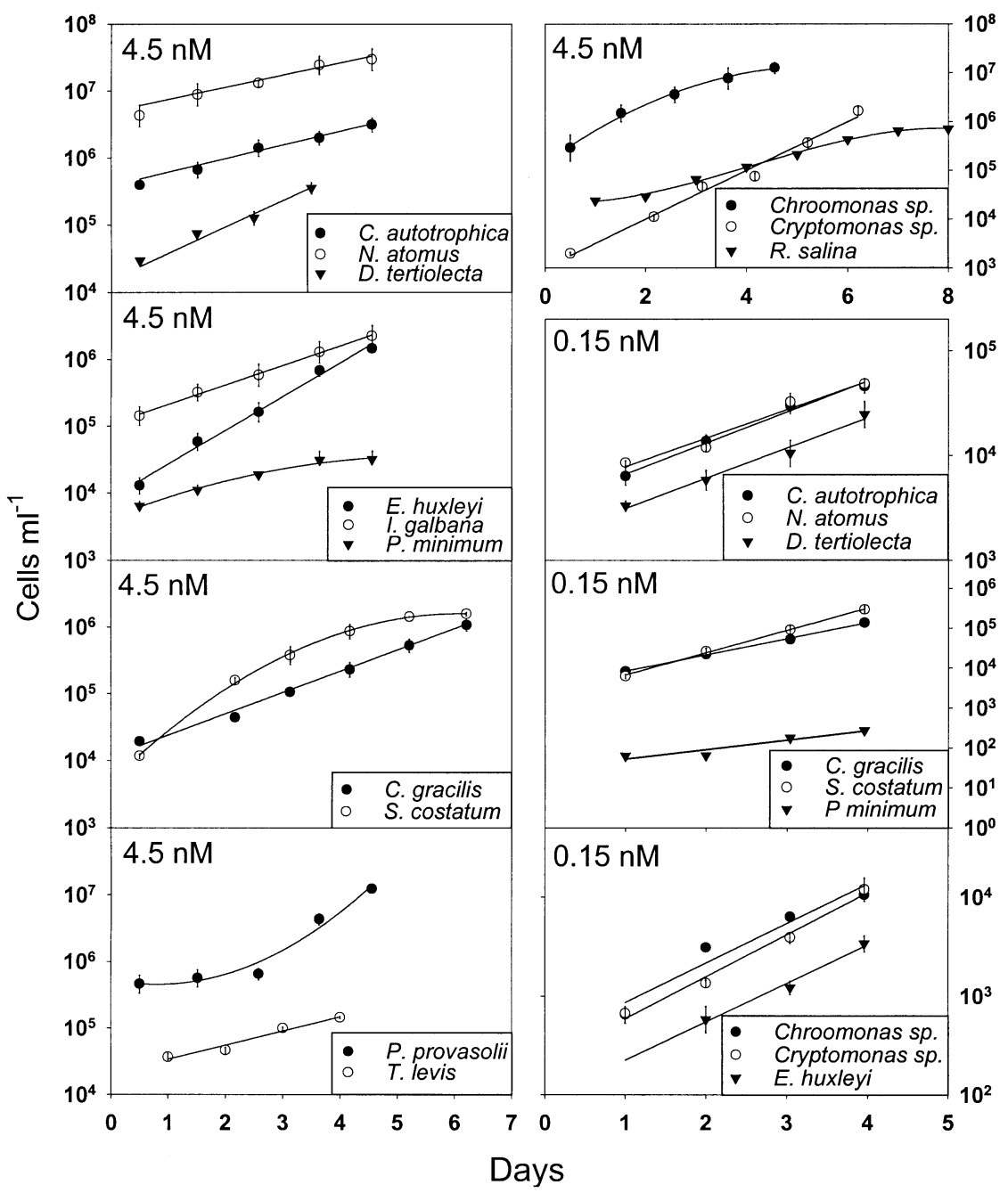

Fig. 1. Cell growth over time for 13 algal species grown at $4.5 \mathrm{nM}$ selenite and 9 algal species grown at $0.15 \mathrm{nM}$. The lines represent fits of exponential or logistic growth curves to the data. Data points are means of 3 replicate cultures \pm 1 SD

All species displayed strong relationships between the total volume of cells $\mathrm{ml}^{-1}, V_{\mathrm{C}}$, and the amount of Se in particles, PSe (Tables $2 \& 3$ ). Most of the regressions were linear, indicating that the amount of Se taken up per cell was constant throughout the experiment. Where uptake of selenite became limited at some point during the experiment, the data were fit to rectangular hyperbolic models. Four species exhibited hyperbolic relationships between PSe and $V_{\mathrm{c}}$ in the $4.5 \mathrm{nM}$ experiments, while 2 species used in the $0.15 \mathrm{nM}$ experiments exhibited such relationships. Generally, the fraction of Se taken up by a given species was similar for the 0.15 and $4.5 \mathrm{nM}$ experiments. Cryptomonas sp., for example, incorporated a maximum of 20 and $25 \%$ of the added selenite in the $4.5 \mathrm{nM}$ and $0.15 \mathrm{nM}$ experiments; for Emiliania huxleyi the same values were 59 and $30 \%$. Experiments with Thalassiosira pseudonana showed that when this species grew to stationary phase on $\mathrm{f} / 2$ it incorporated 65 to $85 \%$ of the added selenite as long as the initial concentration was $<10 \mathrm{nM}$ (Fig. 4). Selenite uptake by Skeletonema costatum increased significantly as the cultures approached stationary phase during the $4.5 \mathrm{nM}$ experiment. This pattern cannot be fit to either the linear or hyperbolic model. Consequently, only the data that preceded declining population growth rates in these cultures were used in the regressions for this species.

The regression estimates of Se cell concentration $\left(\mathrm{Se} / V_{\mathrm{c}} \mathrm{ng} \mu \mathrm{m}^{-3}\right.$ ) varied by almost 4 orders of magnitude in the $4.5 \mathrm{nM}$ experiments $\left(8.7 \times 10^{-6}\right.$ to $5.4 \times 10^{-2}$; Table 2, Fig. 5) and almost 5 orders of magnitude in the $0.15 \mathrm{nM}$ experiments $\left(4.95 \times 10^{-7}\right.$ to $3.37 \times 10^{-2}$; Table 3). Concentration factors for selenite based on these estimates ranged from $2.4 \times 10^{1}$ to $1.5 \times 10^{5}$ in the $4.5 \mathrm{nM}$ experiments and from $4.2 \times 10^{1}$ to $2.8 \times 10^{6}$ in the $0.15 \mathrm{nM}$ experiments (Table 4). Estimated Se:C ratios 


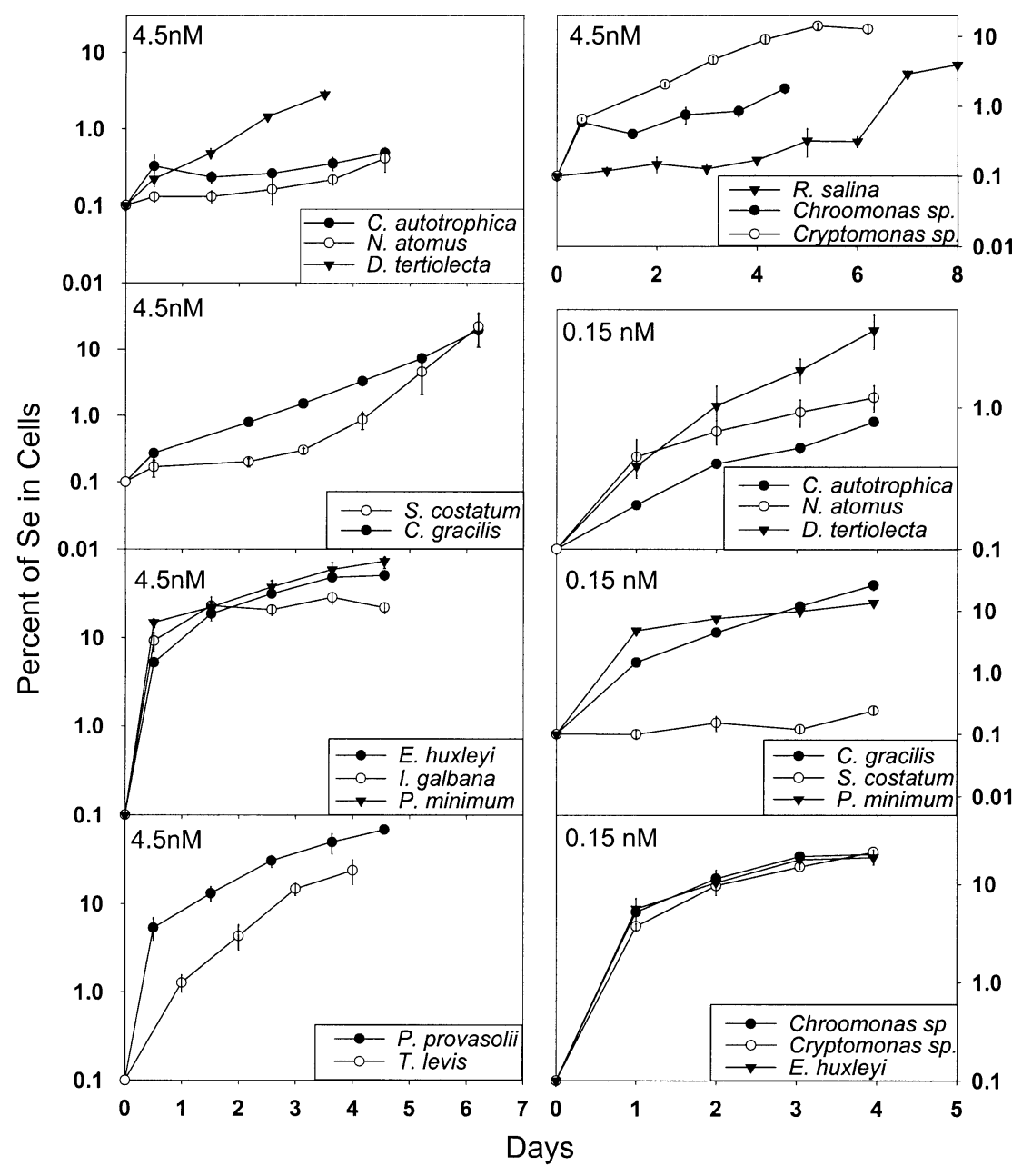

Fig. 2. Percent of Se in particles $>1.0 \mu \mathrm{m}$ over time for 13 algal species grown at $4.5 \mathrm{nM}$ selenite and 9 algal species grown at $0.15 \mathrm{nM}$. Data points are means of 3 replicate cultures $\pm 1 \mathrm{SD}$

Table 2. Regression results and calculation of cellular Se concentration of algae at the initiation of the $4.5 \mathrm{nM}$ selenite uptake experiments. PSe $\mathrm{Max}_{\mathrm{Max}}$ is the maximum amount of Se incorporated into particles and $V_{1 / 2 \mathrm{PSe}}$ is the total cell volume at which PSe is

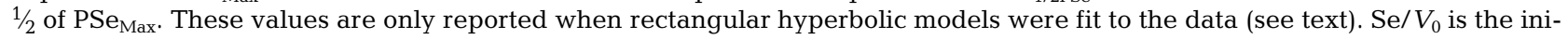
tial concentration of Se per unit volume of cells inferred from either the slope of the linear regression of PSe on total cell volume, or the quotient $\mathrm{PSe}_{\mathrm{Max}} / V_{1 / 2 \mathrm{PSe}}$. p-values are for the models. Values in parentheses $=1 \mathrm{SD}$

\begin{tabular}{|c|c|c|c|c|c|c|}
\hline Species & $\begin{array}{c}\mathrm{PSe}_{\max } \\
\left(\mathrm{ng} \mathrm{m}^{-1}\right)\end{array}$ & $\begin{array}{c}V_{1 / 2 \mathrm{PSe}} \\
\left(\mu \mathrm{m}^{3} \times 10^{6}\right)\end{array}$ & $\begin{array}{c}\mathrm{Se} / V_{0} \\
\left(\mathrm{ng} \mu \mathrm{m}^{-3}\right)\end{array}$ & $\mathrm{n}$ & $\mathrm{p}$-value & $r^{2}$ \\
\hline Chaetoceros gracilis & & & $7.4 \times 10^{-10}\left(2.3 \times 10^{-11}\right)$ & 15 & $<0.0001$ & 0.99 \\
\hline Skeletonema costatum & & & $3.8 \times 10^{-11}\left(4.8 \times 10^{-12}\right)$ & 10 & $<0.0001$ & 0.87 \\
\hline Thalassiosira pseudonana & & & $2.5 \times 10^{-9}\left(2.0 \times 10^{-10}\right)$ & 27 & $<0.0001$ & 0.99 \\
\hline Chlorella autotrophica & & & $1.0 \times 10^{-11}\left(1.5 \times 10^{-12}\right)$ & 13 & $<0.0001$ & 0.79 \\
\hline Dunaliella tertiolecta & & & $1.5 \times 10^{-10}\left(1.1 \times 10^{-11}\right)$ & 12 & $<0.0001$ & 0.94 \\
\hline Nannochloris atomus & & & $8.7 \times 10^{-12}\left(1.8 \times 10^{-12}\right)$ & 15 & 0.0003 & 0.62 \\
\hline Chroomonas sp. & & & $8.6 \times 10^{-11}\left(1.6 \times 10^{-11}\right)$ & 15 & 0.0002 & 0.65 \\
\hline Cryptomonas sp. & $0.072(0.005)$ & $18.7(3.2)$ & $3.9 \times 10^{-9}\left(7.1 \times 10^{-10}\right)$ & 14 & $<0.0001$ & 0.96 \\
\hline Rhodomonas salina & & & $2.6 \times 10^{-11}\left(7.5 \times 10^{-12}\right)$ & 18 & 0.003 & 0.40 \\
\hline Prorocentrum minimum & & & $4.6 \times 10^{-9}\left(6.0 \times 10^{-10^{\prime}}\right)$ & 15 & $<0.0001$ & 0.81 \\
\hline Pycnococcus provasolii & $0.29(0.028)$ & $5.4(1.53)$ & $5.4 \times 10^{-8}\left(1.6 \times 10^{-8}\right)$ & 14 & $<0.0001$ & 0.88 \\
\hline Tetraselmis levis & & & $3.6 \times 10^{-9}\left(5.5 \times 10^{-10}\right)$ & 12 & $<0.0001$ & 0.79 \\
\hline Emiliania huxleyi & $0.21(0.013)$ & $7.21(1.51)$ & $2.9 \times 10^{-8}\left(6.4 \times 10^{-9}\right)$ & 15 & $<0.0001$ & 0.92 \\
\hline Isochrysis galbana & $0.098(0.011)$ & $4.02(2.1)$ & $2.4 \times 10^{-8}\left(1.3 \times 10^{-8}\right)$ & 15 & 0.0033 & 0.46 \\
\hline
\end{tabular}




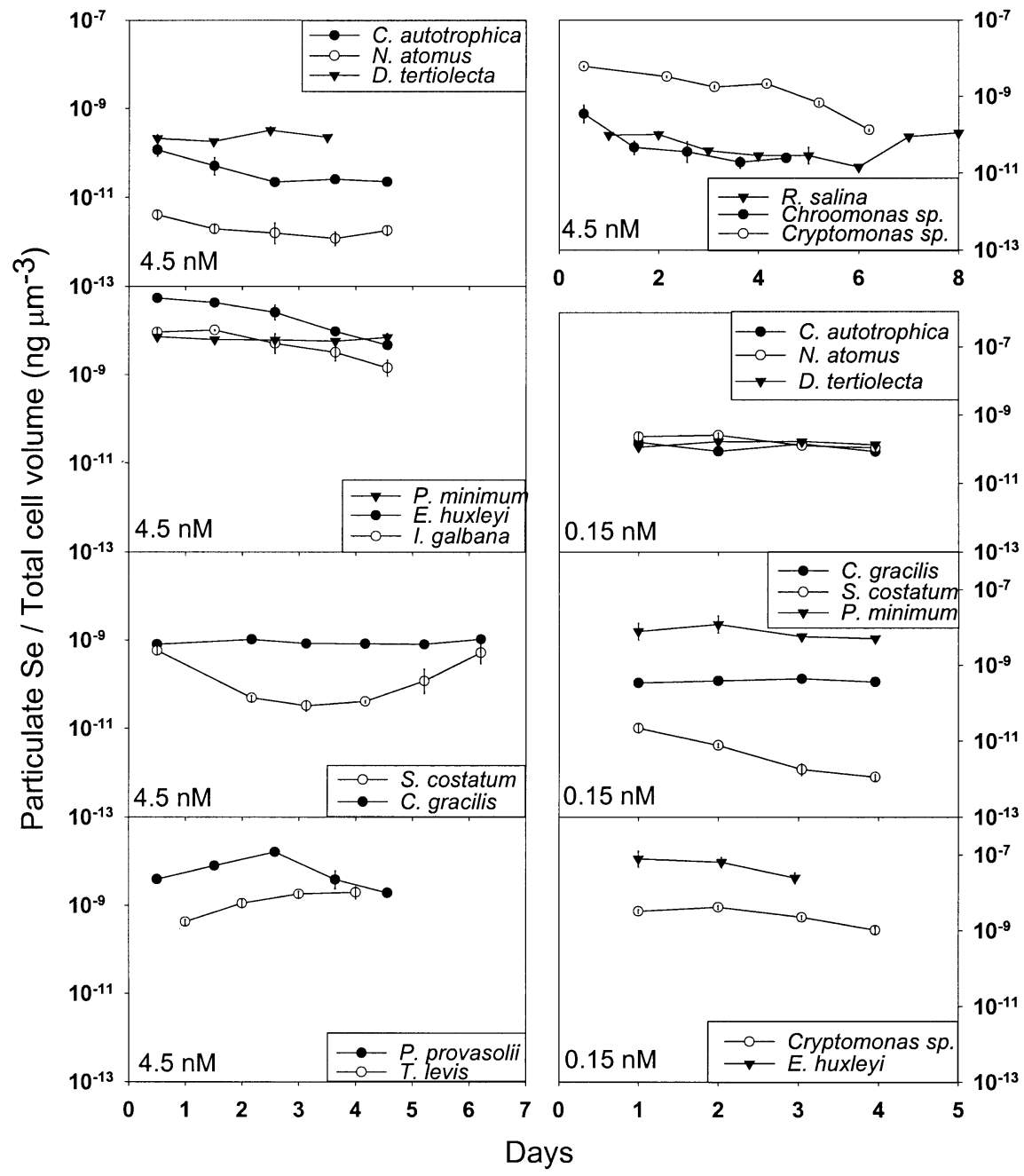

Fig. 3. Time series of Se in particles $>1.0 \mu \mathrm{m}$ normalized to total volume of algal cells for 13 algal species grown at $4.5 \mathrm{nM}$ selenite and 9 algal species grown at $0.15 \mathrm{nM}$. Data points are means of 3 replicate cultures $\pm 1 \mathrm{SD}$

Table 3. Regression results and calculation of cellular Se concentration of algae at the initiation of the $0.15 \mathrm{nM}$ selenite uptake experiments. For details see legend of Table 2

\begin{tabular}{|c|c|c|c|c|c|c|}
\hline Species & $\begin{array}{l}\mathrm{PSe}_{\max } \\
\left(\mathrm{ng} \mathrm{l}^{-1}\right)\end{array}$ & $\begin{array}{c}V_{1 / 2 \mathrm{PSe}} \\
\left(\mu \mathrm{m}^{3} \times 10^{6}\right)\end{array}$ & $\begin{array}{c}\mathrm{Se} / V_{0} \\
\left(\mathrm{ng} \mu \mathrm{m}^{-3}\right)\end{array}$ & $\mathrm{n}$ & p-value & $r^{2}$ \\
\hline Chaetoceros gracilis & & & $3.31 \times 10^{-10}\left(1.20 \times 10^{-11}\right)$ & 12 & $<0.0001$ & 0.99 \\
\hline Skeletonema costatum & & & $4.95 \times 10^{-13}\left(1.07 \times 10^{-13}\right)$ & 12 & 0.0010 & 0.65 \\
\hline Thalassiosira pseudonana & & & $1.09 \times 10^{-9}\left(2.5 \times 10^{-10}\right)$ & 21 & 0.0003 & 0.98 \\
\hline Chlorella autotrophica & & & $4.73 \times 10^{-11}\left(8.05 \times 10^{-12}\right)$ & 9 & 0.0006 & 0.81 \\
\hline Dunaliella tertiolecta & & & $1.21 \times 10^{-10}\left(7.91 \times 10^{-12}\right)$ & 11 & $<0.0001$ & 0.95 \\
\hline Nannochloris atomus & & & $5.46 \times 10^{-11}\left(8.56 \times 10^{-12}\right)$ & 12 & $<0.0001$ & 0.78 \\
\hline Cryptomonas sp. & $3.0 \times 10^{-3}\left(1.2 \times 10^{-4}\right)$ & $0.61(0.071)$ & $4.90 \times 10^{-9}\left(6.01 \times 10^{-10}\right)$ & 12 & $<0.0001$ & 0.98 \\
\hline Prorocentrum minimum & & & $3.08 \times 10^{-9}\left(4.27 \times 10^{-10}\right)$ & 12 & $<0.0001$ & 0.82 \\
\hline Emiliania huxleyi & $3.6 \times 10^{-3}\left(5.9 \times 10^{-4}\right)$ & $0.11(0.042)$ & $3.37 \times 10^{-8}\left(1.45 \times 10^{-8}\right)$ & 12 & $<0.0001$ & 0.96 \\
\hline
\end{tabular}




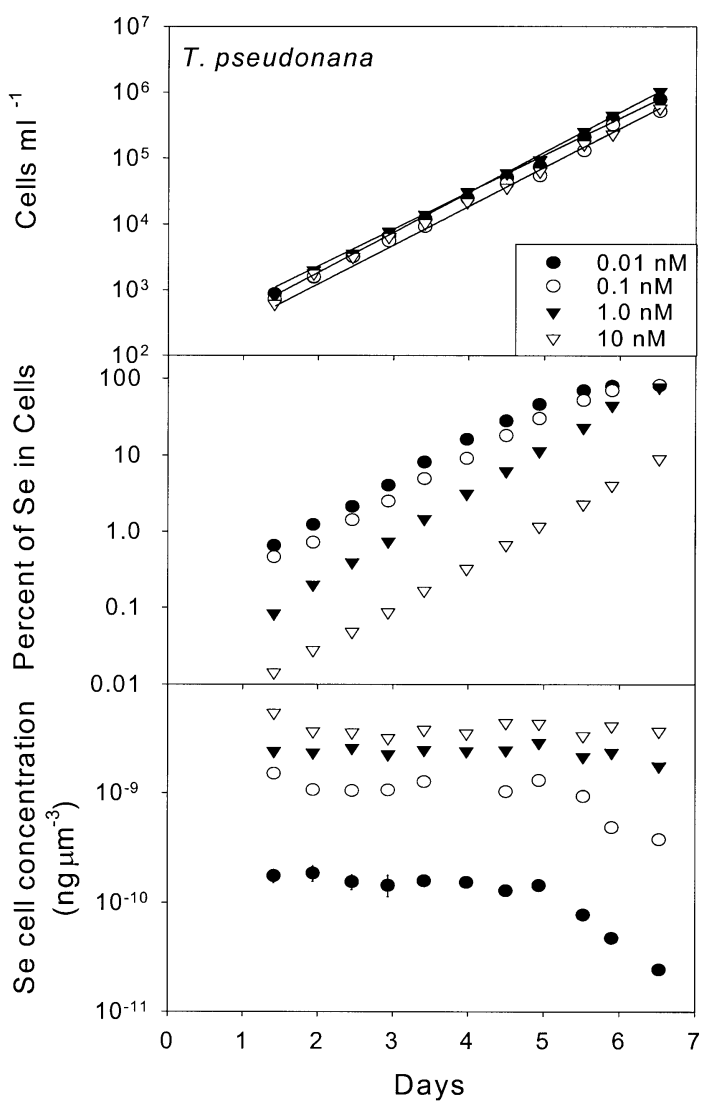

Fig. 4. Thalassiosira pseudonana. Results from experiments at different selenite concentrations. The panels depict time series of cell density (top), Se in particles $>1.0 \mu \mathrm{m}$ (middle), and percent Se in particles $>1.0 \mu \mathrm{m}$ normalized to total volume of algal cells. Solid lines in the top panel show exponential model fits to the data

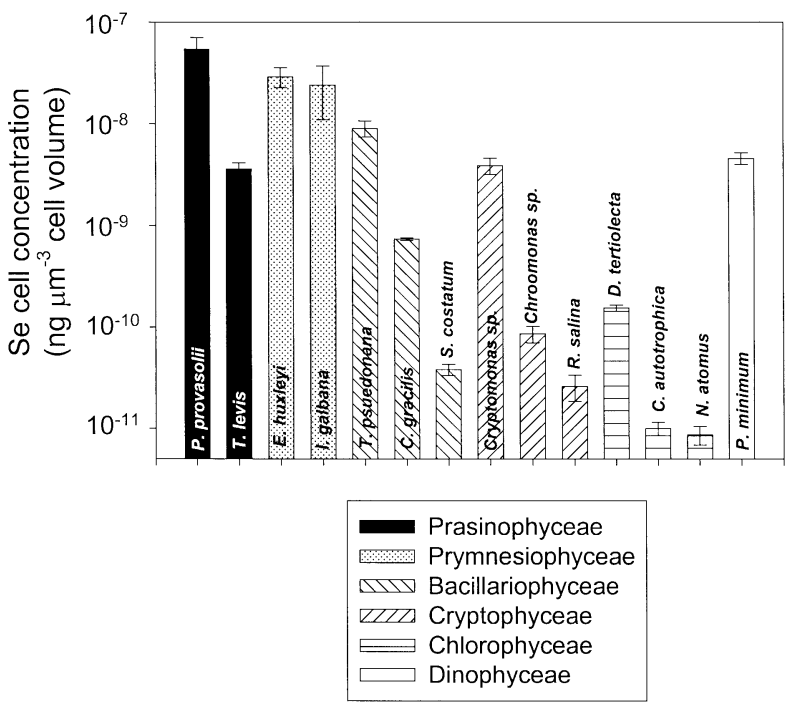

Fig. 5. Comparison of Se concentrations in algae, normalized to cell volume, grown at $4.5 \mathrm{nM}$ selenite. The error bars represent $\pm 1 \mathrm{SD}$

ranged from $0.04 \mu \mathrm{g} \mathrm{Se}{ }^{-1} \mathrm{C}$ for Nannochloris atomus to $217 \mu \mathrm{g} \mathrm{Se} \mathrm{g}^{-1} \mathrm{C}$ for Pycnococcus provasolii (Table 5). Among the 6 divisions, chlorophytes exhibited the lowest Se enrichment. The bacillariophytes and the cryptophytes exhibited $>2$ orders of magnitude variability in Se concentration, with some species in these groups having values as low as the chlorophytes and others being among the most Se-rich. All prymnesiophytes, prasinophytes and dinophytes had Se concentrations that exceeded $1 \times 10^{-9} \mathrm{ng} \mathrm{mm}^{-3}$. Variances differed significantly among groups (Bartlett's test, $\mathrm{p}<0.0001$ ), so a

Table 4. Volume/volume concentration factors for selenite at the 2 experimental concentrations. Ratio is the concentration factor from the $0.15 \mathrm{nM}$ experiment divided by the concentration factor from the $4.5 \mathrm{nM}$ experiment. nd: not determined

\begin{tabular}{|c|c|c|c|c|c|c|c|}
\hline Species & Mean & $\begin{array}{c}4.5 \mathrm{nM} \\
+95 \% \mathrm{CI}\end{array}$ & $-95 \% \mathrm{CI}$ & Mean & $\begin{array}{c}0.15 \mathrm{nM} \\
+95 \% \mathrm{CI}\end{array}$ & $-95 \% \mathrm{CI}$ & Ratio \\
\hline Chaetoceros gracilis & $2.1 \times 10^{3}$ & $2.2 \times 10^{3}$ & $1.9 \times 10^{3}$ & $2.8 \times 10^{4}$ & $3.0 \times 10^{4}$ & $1.0 \times 10^{3}$ & 13.4 \\
\hline Skeletonema costatum & $1.1 \times 10^{2}$ & $1.4 \times 10^{2}$ & $7.8 \times 10^{1}$ & $4.2 \times 10^{1}$ & $6.1 \times 10^{1}$ & $9 \times 10^{0}$ & 0.4 \\
\hline Thalassiosira pseudonana & $2.5 \times 10^{4}$ & $3.5 \times 10^{4}$ & $1.6 \times 10^{4}$ & $4.5 \times 10^{5}$ & $3.1 \times 10^{5}$ & $5.9 \times 10^{5}$ & 17.6 \\
\hline Chlorella autotrophica & $2.8 \times 10^{1}$ & $3.7 \times 10^{1}$ & $1.9 \times 10^{1}$ & $4.0 \times 10^{3}$ & $5.4 \times 10^{3}$ & $6.8 \times 10^{2}$ & 142.8 \\
\hline Dunaliella tertiolecta & $4.3 \times 10^{2}$ & $5.0 \times 10^{2}$ & $3.7 \times 10^{2}$ & $1.0 \times 10^{4}$ & $1.2 \times 10^{4}$ & $6.7 \times 10^{2}$ & 23.7 \\
\hline Nannochloris atomus & $2.4 \times 10^{1}$ & $3.5 \times 10^{1}$ & $1.4 \times 10^{1}$ & $4.6 \times 10^{3}$ & $6.1 \times 10^{3}$ & $7.2 \times 10^{2}$ & 192.1 \\
\hline Chroomonas sp. & $2.4 \times 10^{2}$ & $3.4 \times 10^{2}$ & $1.5 \times 10^{2}$ & nd & - & - & - \\
\hline Cryptomonas sp. & $1.1 \times 10^{4}$ & $1.5 \times 10^{4}$ & $6.7 \times 10^{3}$ & $4.1 \times 10^{5}$ & $5.2 \times 10^{5}$ & $5.1 \times 10^{4}$ & 37.6 \\
\hline Rhodomonas salina & $7.3 \times 10^{1}$ & $1.2 \times 10^{2}$ & $2.8 \times 10^{1}$ & nd & - & - & - \\
\hline Prorocentrum minimum & $1.3 \times 10^{4}$ & $1.7 \times 10^{4}$ & $9.3 \times 10^{3}$ & $2.6 \times 10^{5}$ & $3.4 \times 10^{5}$ & $3.6 \times 10^{4}$ & 20.1 \\
\hline Pycnococcus provasolii & $1.5 \times 10^{5}$ & $2.5 \times 10^{5}$ & $5.5 \times 10^{4}$ & nd & - & - & - \\
\hline Tetraselmis levis & $1.0 \times 10^{4}$ & $1.3 \times 10^{4}$ & $6.8 \times 10^{3}$ & nd & - & - & - \\
\hline Emiliania huxleyi & $8.2 \times 10^{4}$ & $1.2 \times 10^{5}$ & $4.3 \times 10^{4}$ & $2.8 \times 10^{6}$ & $5.4 \times 10^{6}$ & $1.2 \times 10^{6}$ & 34.9 \\
\hline Isochrysis galbana & $6.8 \times 10^{4}$ & $1.5 \times 10^{5}$ & $3.8 \times 10^{4}$ & nd & - & - & - \\
\hline
\end{tabular}


Table 5. Se:C ratios estimated from Se uptake experiments and cell volume (Table 1) for the 4.5 and $0.15 \mathrm{nM}$ experiments. The critical ratio is the algal Se:C divided by the critical Se:C of 13.2 (see text for calculations). The critical biomass contribution is the minimum fractional contribution of the species to total community algal biomass needed to cause the Se:C ratio of the entire phytoplankton community to reach the critical Se. Where this value is $>100 \%$, the critical biomass contribution is left blank. nd: not determined

\begin{tabular}{|c|c|c|c|c|c|c|}
\hline & \multicolumn{3}{|c|}{$4.5 \mathrm{nM}$ experiments } & \multicolumn{3}{|c|}{$0.15 \mathrm{nM}$ experiments } \\
\hline & $\begin{array}{c}\text { Se:C } \\
\left(\mu g g^{-1}\right)\end{array}$ & $\begin{array}{l}\text { Critical } \\
\text { ratio }\end{array}$ & $\begin{array}{l}\text { Critical biomass } \\
\text { contribution }\end{array}$ & $\begin{array}{c}\text { Se:C } \\
\left(\mu g g^{-1}\right)\end{array}$ & $\begin{array}{l}\text { Critical } \\
\text { ratio }\end{array}$ & $\begin{array}{l}\text { Critical biomass } \\
\text { contribution }\end{array}$ \\
\hline Chaetoceros gracilis & 3.63 & 0.28 & & 2.37 & 0.18 & \\
\hline Skeletonema costatum & 0.21 & 0.02 & & nd & - & - \\
\hline Thalassiosira pseudonana & 15.6 & 1.18 & $85 \%$ & 6.81 & 0.52 & \\
\hline Chlorella autotrophica & 0.05 & 0.004 & & 0.22 & 0.02 & \\
\hline Dunaliella tertiolecta & 0.89 & 0.07 & & 0.7 & 0.05 & \\
\hline Nannochloris atomus & 0.04 & 0.003 & & 0.25 & 0.02 & \\
\hline Chroomonas sp. & 0.38 & 0.03 & & nd & - & - \\
\hline Cryptomonas sp. & 24.2 & 1.83 & $55 \%$ & 30.4 & 2.3 & $43 \%$ \\
\hline Rhodomonas salina & 0.16 & 0.01 & & nd & - & - \\
\hline Prorocentrum minimum & 36.6 & 2.77 & $36 \%$ & 24.5 & 1.86 & $54 \%$ \\
\hline Pycnococcus provasolii & 217 & 16.4 & $6 \%$ & nd & - & - \\
\hline Tetraselmis levis & 23.5 & 1.78 & $56 \%$ & nd & - & - \\
\hline Emiliania huxleyi & 134 & 10.2 & $10 \%$ & 156 & 11.8 & $8 \%$ \\
\hline Isochrysis galbana & 110 & 8.33 & $12 \%$ & nd & - & - \\
\hline
\end{tabular}

non-parametric ANOVA (Welch's Studentized ANOVA) was used to test for differences among means. Differences in $\mathrm{Se} / V_{\mathrm{c}}$ were statistically significant at the 0.05 level using this test $(p=0.029)$.

Of the 9 species whose uptake of selenite was measured at both 0.15 and $4.5 \mathrm{nM}$ selenite, only Skele-

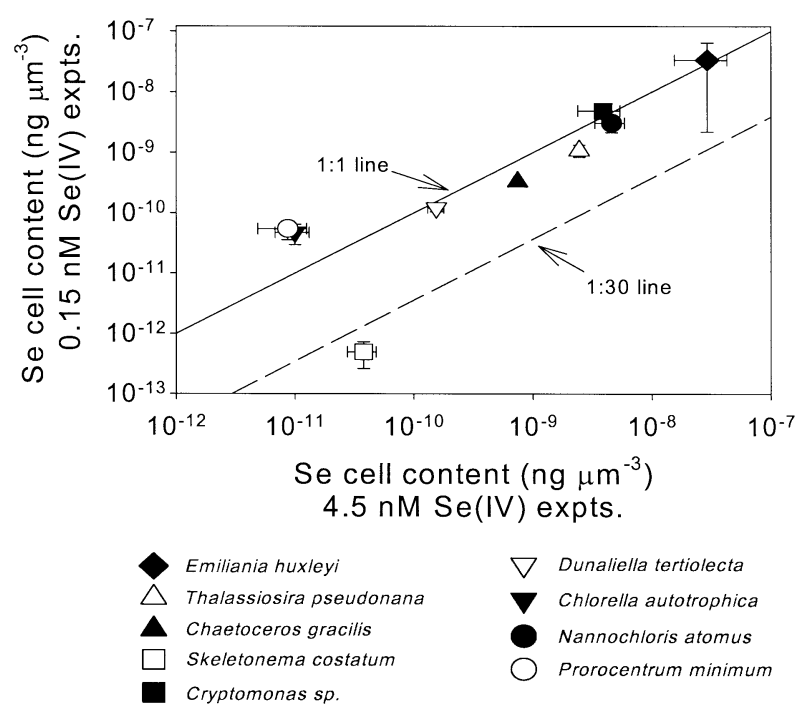

Fig. 6. Comparison of algal Se concentrations for cells grown at 4.5 and $0.15 \mathrm{nM}$ selenite. The solid line represents the case where Se cell ${ }^{-1}$ is constant regardless of ambient selenite concentration. The dashed line represents the case where Se cell ${ }^{-1}$ varies in direct proportion to external selenite concentration tonema costatum varied its Se cell content in direct proportion to ambient selenite concentrations (Table 4, Fig. 6). When cellular Se concentration from the 0.15 and $4.5 \mathrm{nM}$ experiments are plotted against each other, most of the values are less than 2- to 3-fold below the 1:1 line. Because cellular Se concentration does not decline in proportion to selenite concentration, the volume/volume concentration factors $(\mathrm{VCF}=\mathrm{ng} \mathrm{Se}$ $\mu \mathrm{m}^{-3}$ cell/ng Se $\mu \mathrm{m}^{-3}$ water [dissolved]) are generally at least an order of magnitude higher at $0.15 \mathrm{nM}$ than at $4.5 \mathrm{nM}$ (Table 4). S. costatum, on the other hand, has a slightly lower concentration factor at the lower selenite concentration.

Thalassiosira pseudonana exhibited dynamics that was very similar to the other species (Fig. 4). Growth was logarithmic at all concentrations of selenite, and growth rates were indistinguishable among the experiments. The fraction of total Se in the particulate pool increased logarithmically as well, except for the last few observations of the 2 experiments with the lowest initial selenite concentrations $(0.01$ and $0.1 \mathrm{nM})$. Regression estimates of Se cell concentration $\left(\mathrm{Se} / V_{\mathrm{c}}\right)$ varied non-linearly with ambient selenite concentration. Se cell concentration differed 7 -fold $\left(1.5 \times 10^{-10}\right.$ to $\left.1.1 \times 10^{-9} \mathrm{ng} \mathrm{Se} \mu \mathrm{m}^{-3}\right)$ between the 0.01 to $0.1 \mathrm{nM}$ experiments. In comparison, the Se cell concentration at the 3 highest selenite concentrations $(0.1,1.0$ and $10 \mathrm{nM})$ differed by only 3.5 -fold $\left(1.1 \times 10^{-9}\right.$ to $\left.3.49 \times 10^{-9} \mathrm{ng} \mathrm{Se} \mu \mathrm{m}^{-3}\right)$, indicating saturation of selenite incorporation into cellular material (Fig. 7). 


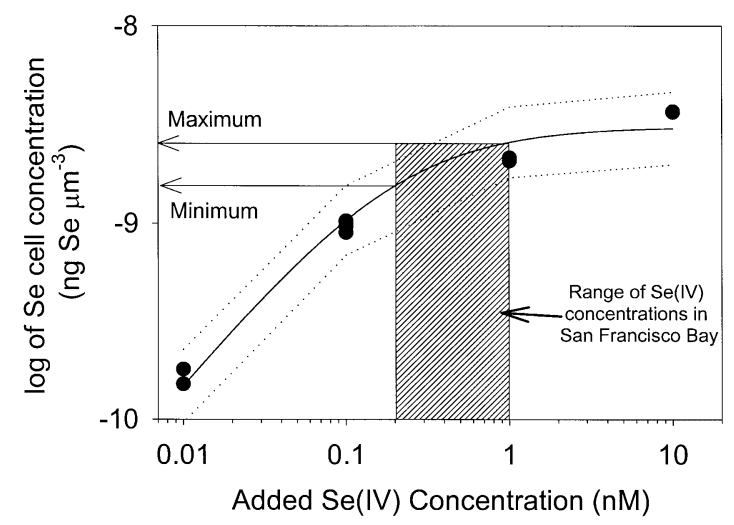

Fig. 7. Relationship between Thalassiosira pseudonana Se cell concentration and external selenite concentration. The line represents the best fit line for a rectangular hyperbola fit to the data $\left(p<0.0001, r^{2}=0.98\right)$. The shaded area depicts the range of selenite concentrations observed historically in northern San Francisco Bay

\section{DISCUSSION}

\section{Taxonomic variability}

The selective uptake of selenite indicated by the wide range of $\mathrm{Se} / V_{\mathrm{c}}$ ratios suggests that strong biological control is exerted over selenite uptake, as noted previously (Wrench \& Measures 1982, Vandermeulen \& Foda 1988, Fisher \& Wente 1993). This range in uptake can be contrasted with many metals that are primarily taken up via adsorption. These elements tend to exhibit similar uptake per unit surface area for a broad array of biological and abiotic particles (Fisher \& Reinfelder 1995).

There were statistically significant differences in Se concentration among the algal divisions (Fig. 5). All the chlorophytes uniformly exhibited low Se concentrations, while all the dinoflagellates, prasinophytes, and prymnesiophytes concentrated selenite very effectively. However, the variability within the diatoms and the cryptophytes and the small number of species sampled within each algal division suggest that it would be premature to accept these differences between groups as general. The chlorophytes and the prasinophytes, perhaps the most closely related of the groups tested here, exhibited very different tendencies to accumulate selenite. For terrestrial plants selenite assimilation and sensitivity to soil selenite can also vary widely among very closely related species (e.g., of the genus Astragalus; Brown \& Shrift 1982).

The cellular Se concentration of algae does not appear to correspond with differing requirements for Se. Se requirements have been documented for some species of diatoms and dinoflagellates (Harrison et al.
1988). Both Skeletonema costatum and Thalassiosira pseudonana exhibit requirements for $\mathrm{Se}$, while exhibiting widely divergent cellular Se concentrations. It seems, moreover, that at least some algae concentrate Se far more than they require. For example, while $T$. pseudonana has a known requirement for Se (Price et al. 1987), it grows at the same rate even when variable initial selenite concentrations in media cause final cell quotas to differ by over 2 orders of magnitude (Fig. 4). Harrison et al. (1988) often found it necessary to transfer cultures of various diatoms and dinoflagellates to Se-free media several times before Se limitation became apparent. We conclude that much of the intracellular Se is nonessential when cells are at their maximum Se content.

Algal Se content may vary in some species depending on the phase of growth (Figs. 2 \& 3), as displayed most clearly in Skeletonema costatum. When the cultures of this species began to approach stationary phase, the Se concentration increased by nearly an order of magnitude. Late log phase S. costatum cells attained Se concentrations approaching those for Chaetoceros gracilis, an intermediate Se accumulator. Rhodomonas salina also showed a clear but less significant increase in selenite concentration as cell growth slowed.

The species studied vary significantly not only in their Se concentrations, but in the fraction of added selenite that could be incorporated by them. The species which most effectively concentrated selenite ceased taking up Se after 20 to $80 \%$ (depending on the species) of the added selenite was assimilated, even though cells continued to proliferate (Tables 2 \& 3). Several studies have observed that algae can excrete organic selenides after assimilating selenite (Vandermeulen \& Foda 1988, Besser et al. 1994, Hu et al. 1997). Those studies showed that dissolved organic selenide can accounted for 20 to $35 \%$ of the added selenite in cultures after a few days of algal growth. It is possible that much of the residual dissolved Se in cultures containing Se accumulating species was in the form of dissolved organic selenides.

\section{Concentration effects}

With the exception of Skeletonema costatum, the Se concentration of phytoplankton cells did not vary in direct proportion to selenite concentrations but remained almost constant over a 30-fold variation in ambient selenite (from 0.15 to $4.5 \mathrm{nM}$ ). The cellular Se concentration varied greatly between 0.01 and $0.1 \mathrm{nM}$ of added selenite, above which the cell Se content varied much less with ambient concentration. Cell growth rates were not correlated to selenite concentra- 
tion and did not slow as Se concentration declined toward the end of the 0.01 and $0.1 \mathrm{nM}$ experiments, indicating that physiological Se limitation never occurred in these experiments. These results suggest that uptake of selenite is an enzymatically mediated process, at least over the experimental concentrations investigated.

Our results also suggest that the range of variability in selenite concentrations observed in northern San Francisco Bay will produce modest changes in the Se concentration of most of the algae studied here. Using the parameters of a rectangular hyperbola fit to the data in Fig. 7 and assuming that selenite concentrations in the northern reaches of San Francisco Bay range from 0.1 to $1 \mathrm{nM}$ (Cutter 1989), we estimate that the Se of Thalassiosira pseudonana cells would vary only about $65 \%$ over this 10 -fold change in ambient selenite concentrations. The tendency for the Se concentrations of other algal species to vary only 2 - to 3 -fold when selenite varied from 0.15 to $4.5 \mathrm{nM}$ suggests that they also may exhibit near saturation of Se concentration at relatively low selenite concentrations.

Our results should be applicable to other estuaries in addition to San Francisco Bay. Selenite concentrations in many estuaries are $0.2 \mathrm{nM}$ or greater (Cutter 1989) and are thus higher than the lower experimental concentration used in our study. Estuaries impacted by heavy industrial inputs (e.g., the Scheldt estuary) can have selenite concentrations many times higher than $0.2 \mathrm{nM}$ (Cutter 1989). It seems clear from our study that the species composition of the phytoplankton community may be an overriding determinant influencing the Se concentration in the phytoplankton biomass in these waters. However, in coastal and open ocean regions, where selenite concentrations are often $<0.1 \mathrm{nM}$ (Cutter \& Bruland 1984), our results suggest that variability in concentration of selenite may have a strong effect on the Se concentration in algal cells.

Our results seem to contradict past work relating ambient selenite concentration to Se concentration in algal cells. Riedel et al. (1991) found that 3 species of freshwater algae increased their gross uptake rates of selenite in relation to external selenite concentrations up to concentrations of $90 \mathrm{nM}$. However, those authors also suggested that much of the uptake of selenite by cells was via abiotic adsorption, since dead cells accumulated selenite almost as readily as live ones and uptake did not show a strong tendency to reach an asymptote with increasing concentration. Riedel et al. (1996) argued that such adsorption is not surprising given the low ionic strength and $\mathrm{pH}$ of freshwater. Adsorption may also explain the freshwater algae dose-response curves for selenite that indicate the onset of toxicity at mM concentrations of selenite (i.e., $10^{6} \times$ greater than our experimental concentrations). By contrast, adsorption of selenite by dead marine phytoplankton cells was found to be negligible (Fisher \& Wente 1993). This is consistent with the widely varying Se uptake per unit cell volume or carbon (Tables $3 \& 5$ ), suggesting strong biological control of uptake of this element. Vandermeulen \& Foda (1988) also observed a direct relationship between selenite concentration and accumulation by marine algae as selenite concentrations varied from $\mathrm{nM}$ to $\mathrm{mM}$ concentrations. However, while they did not observe saturation of cellular Se concentration at high selenite concentrations, they found that the cellular Se concentration increased only 3 -fold for every 10 -fold increase in ambient selenite concentration.

\section{Implications for Se toxicity to higher level consumers}

Kinetic modeling provides a means of determining if the Se concentrations of algal cells measured in this study are sufficient to cause dangerously high Se tissue contents in herbivores (Luoma et al. 1992, Wang et al. 1996). In this exercise we used the mussel Mytilis edulis as a target consumer, because of its widespread use in biomonitoring and because many of the relevant biokinetic parameters have been assessed for this species (Wang et al. 1996, Wang \& Fisher 1999). In making the calculations we also use environmental conditions relevant to North San Francisco Bay.

Because almost all the Se in bivalve filter feeders derives from food (Luoma et al. 1992, Wang et al. 1996), we assessed Se accumulation via this pathway only. According to the field-tested bioaccumulation model describing contaminant uptake in mussels (Wang et al. 1996), the concentration of an ingested metal in a mussel's tissues reaches a steady-state value $C_{\mathrm{ss}}$ ( $\mu \mathrm{g}$ metal $\mathrm{g}^{-1}$ dry wt) that is related to the concentration in food according to

$$
C_{\mathrm{ss}}=\frac{\mathrm{AE} \cdot \mathrm{IR} \cdot C_{\mathrm{f}}}{k_{\mathrm{ef}}+g}
$$

where IR is the ingestion rate $\left(\mathrm{mg} \mathrm{g}^{-1} \mathrm{~d}^{-1}\right), C_{\mathrm{f}}$ is the concentration of the contaminant in the food $\left(\mu \mathrm{g} \mathrm{g}^{-1}\right)$, $\mathrm{AE}$ is the percentage of the ingested contaminant that is assimilated across the gut and into the animal, $g$ is the growth rate of the mussel $\left(\mathrm{d}^{-1}\right)$, and $k_{\text {ef }}$ is the efflux rate constant for contaminant assimilated from food $\left(d^{-1}\right)$. Eq. (3) can be rearranged to solve for a concentration of Se in food that yields a target concentration in mussels. Since an Se tissue concentration in Mytilus edulis of $10 \mu \mathrm{g} \mathrm{Se}^{-1}$ dry wt is potentially dangerous to upper trophic level consumers of bivalves (Luoma et al. 1992), we set this concentration as a 'target' for our calculations. In these calculations, we assume that the 
growth rate dilution term of the mussel is negligible (Wang et al. 1996).

Chlorophyll concentrations in the northern reaches of San Francisco Bay are typically $2 \mu \mathrm{g} \mathrm{l}^{-1}$ (Cutter 1989). Assuming a C:chl ratio of 50:1 and a C:dry wt ratio of 1:4 for algae, this concentration of chlorophyll is equivalent to about $0.4 \mathrm{mg}$ dry $\mathrm{wt}^{-1}$ of suspended algae. Equations developed by Bayne et al. (1987, 1993) predict that ingestion rates for Mytilus edulis on algae at this concentration should be $93 \mathrm{mg} \mathrm{g}^{-1}$ dry wt $\mathrm{d}^{-1}$. Given an AE of $75 \%$ (Reinfelder et al. 1997) and a $k_{\text {ef }}$ of $0.022 \mathrm{~d}^{-1}$ (Wang et al. 1996), we estimate that a

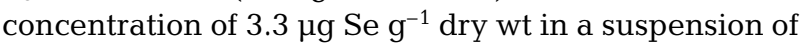
pure algae is necessary to achieve a body burden of $10 \mathrm{\mu g} \mathrm{g}^{-1}$ dry wt in mussels. This value translates into a Se:C ratio in algae of about $13.2 \mu \mathrm{g} \mathrm{Se} \mathrm{g}^{-1} \mathrm{C}$, again assuming a 1:4 C:dry wt conversion.

The Se:C ratios of half the species grown at $4.5 \mathrm{nM}$ selenite and 3 of the 9 species grown at $0.15 \mathrm{nM}$ selenite exceeded the critical value of Se:C or $13.2 \mu \mathrm{g} \mathrm{Se} \mathrm{g}^{-1}$ C. Thalassiosira pseudonana was the only alga that was above the critical Se:C ratio at $4.5 \mathrm{nM}$, but below it at $0.15 \mathrm{nM}$. All of the chlorophytes had Se:C well below the critical level. Some species (e.g., Emiliania huxleyi, Isochrysis galbana, and Pycnococcus provasolii) had Se concentrations well above the critical level. For a mixed phytoplankton community to have an overall Se:C ratio above the threshold, these species would need to comprise only $10 \%$ of the algal biomass. Another group of algae had cellular Se concentrations that were essentially indistinguishable from the critical limit of $13.2 \mu \mathrm{g} \mathrm{Se} \mathrm{g}^{-1} \mathrm{C}$. These algae included $T$. pseudonana, Cryptomonas sp., Tetraselmis levis and Prorocentrum minimum. All the other algae had Se concentrations that were always $<27 \%$ and usually $<10 \%$ of the critical Se concentration.

\section{Implications for management}

The traditional dependence on concentration factors to predict Se concentrations in organisms from water concentrations and thereby set water quality criteria may be misleading. This approach is most effective when target organisms, or the food of those organisms, obtain much of the contaminant of interest via direct adsorption from the dissolved phase. However, food, not the dissolved phase, is the primary source of Se for marine consumers. Even the organisms that are primarily responsible for concentrating selenite from solution (algae) do no not appear to respond in a simple linear manner to selenite concentrations. Further, concentration factors vary greatly among algal species, so that significant temporal and spatial variations in particulate Se concentrations could occur as phyto- plankton communities vary in composition. Thus, what might be a safe concentration of selenite for one phytoplankton assemblage may be dangerous when another set of species predominates. Potential variation in Se concentration factors must be considered when setting water quality criteria.

Novel monitoring strategies that account for community shifts in the phytoplankton may be needed to effectively predict Se toxicity in target areas. Unfortunately, we could discern only rough associations between broad taxonomic groupings and algal Se concentration that would simplify the process of monitoring for algal communities or modeling Se dynamics. An alternative approach would be to identify and target species known to concentrate Se effectively, and to be preferred prey of critical herbivores. This approach would be particularly effective in environments that tend to be dominated by a few key species, or in assessing the effect of bloom species on ecosystems. However, the approach may be problematic where diversity is greater, since rather rare species can make important contributions to the Se content of the total phytoplankton biomass. More promising may be the application of X-ray fluorescence microscopy to assess directly Se concentrations in individual phytoplankton cells. If, as suggested by our results, species differ in their Se concentrations by orders of magnitude regardless of the ambient selenite concentration, such measurements could be used in combination with field observations of phytoplankton diversity to predict the Se concentration in suspended phytoplankton biomass.

In estuaries, or other environments where large quantities of seston can mask the presence of algae with high Se concentrations, process studies that simultaneously measure Se and C uptake ratios should be informative. Such uptake rates could be correlated with seasonal or inter-annual changes in phytoplankton community structure. Because detritus represents a long-term average of the living biomass from which it is derived, the detrital pool of organic Se may be less sensitive to short-term taxonomic shifts, and more responsive to long-term shifts in Se inputs and concentrations than is the phytoplankton community. At present we know little of the relative importance of detrital and phytoplankton pathways in supplying Se to herbivores in estuaries, although assimilation of Se in marine copepods from natural seston was shown to be only slightly less than from diatom cultures $(50 \%$ vs $59 \%$ ) (Wang \& Fisher 1998).

\section{Conclusions}

Among metals and metalloids, Se is an unusual element in that its cycling and biochemical fixation is 
closely tied to that of organic matter, and yet it is not uniformly required by organisms. Thus, phytoplankton cells can exhibit great plasticity in their Se content with little apparent cost. Some phytoplankton species have also developed uptake systems with very high affinities for selenite. Combined, these factors lead to substantial diversity in the ability of phytoplankton species to concentrate Se. At least in estuaries, this variability is large compared to the effects of varying selenite concentration. Consequently, purely ecological axes may be at least as important in determining Se cycles as are standard biogeochemical inputs and outputs. Monitoring and management programs for Se contamination will need to consider these factors in implementation of appropriate strategies.

Acknowledgements. We thank Greg Cutter, Sam Luoma and Martina Doblin for their advice in the planning and interpretation of these experiments, and anonymous reviewers for constructive comments on the manuscript. This research was supported by grants from NSF (OCE9714308) and CalFed (B103). This is Contribution No. 1204 from the Marine Sciences Research Center.

\section{LITERATURE CITED}

Bayne BL, Hawkins AJS, Navarro E (1987) Feeding and digestion by the mussel Mytilus edulis (Bivalvia: Mollusca) in mixtures of silt and algal cells at low concentrations. J Exp Mar Biol Ecol 111:1-22

Bayne BL, Iglesias JIP, Hawkins AJS, Navarro E, Heral M, Deslouspaoli JM (1993) Feeding behavior of the mussel, Mytilus edulis: responses to variations in quantity and organic content of the seston. J Mar Biol Assoc UK 73: 813-829

Besser JM, Huckins JN, Clark RC (1994) Separation of selenium species released from Se-exposed algae. Chemosphere 29:771-780

Bottino NR, Banks CH, Irgolic KJ, Micks P, Wheeler AE, Zingaro RA (1984) Selenium containing amino-acids and proteins in marine-algae. Phytochemistry 23:2445-2452

Brown TA, Shrift A (1982) Selenium-toxicity and tolerance in higher-plants. Biol Rev Camb Philos Soc 57:59-84

Cutter GA (1989) The estuarine behavior of selenium in San Francisco Bay. Estuar Coastal Shelf Sci 28:13-34

Cutter GA, Bruland KW (1984) The marine biogeochemistry of selenium: a re-evaluation. Limnol Oceanogr 29:1179-1192

Fisher NS, Reinfelder JR (1991) Assimilation of selenium in the marine copepod Acartia tonsa studied with a radiotracer ratio method. Mar Ecol Prog Ser 70:157-164

Fisher NS, Reinfelder JR (1995) The trophic transfer of metals in marine systems. In: Tessier A, Turner DR (eds) Metal speciation and bioavailability in aquatic systems. John Wiley \& Sons, Chichester, p 363-406

Fisher NS, Wente M (1993) The release of trace-elements by dying marine-phytoplankton. Deep-Sea Res 40:671-694

Fisher NS, Bjerregaard P, Fowler SW (1983) Interactions of marine plankton with transuranic elements. 1. Biokinetics

Editorial responsibility: Otto Kinne (Editor),

Oldendorf/Luhe, Germany of neptunium, plutonium, americium, and californium in phytoplankton. Limnol Oceanogr 28:432-447

Foda A, Vandermeulen JH, Wrench JJ (1983) Uptake and conversion of selenium by a marine bacterium. Can J Fish Aquat Sci 40:215-220

Harrison PJ, Yu PW, Thompson PA, Price NM, Phillips DJ (1988) Survey of selenium requirements in marine-phytoplankton. Mar Ecol Prog Ser 47:89-96

Hu MH, Yang YP, Martin JM, Yin K, Harrison PJ (1997) Preferential uptake of $\mathrm{Se}(\mathrm{IV})$ over $\mathrm{Se}(\mathrm{VI})$ and the production of dissolved organic Se by marine phytoplankton. Mar Environ Res 44:225-231

Lehman PW (1996) Changes in chlorophyll a concentration and phytoplankton community composition with wateryear type in the upper San Francisco Bay estuary. In: Hollibaugh JT (ed) San Francisco Bay: the ecosystem. Pacific Div. AAAS, San Francisco, p 351-373

Lemly AD (1985) Toxicology of selenium in a fresh-water reservoir-implications for environmental-hazard evaluation and safety. Ecotoxicol Environ Safety 10:314-338

Lindstrom K (1991) Nutrient-requirements of the dinoflagellate Peridinium gatunense. J Phycol 27:207-219

Luoma SN, Johns C, Fisher NS, Steinberg NA, Oremland RS, Reinfelder JR (1992) Determination of selenium bioavailability to a benthic bivalve from particulate and solute pathways. Environ Sci Technol 26:485-491

Price NM, Thompson PA, Harrison PJ (1987) Selenium-an essential element for growth of the coastal marine diatom Thalassiosira pseudonana (Bacillariophyceae). J Phycol 23:1-9

Reinfelder JR, Fisher NS (1994) The assimilation of elements ingested by marine planktonic bivalve larvae. Limnol Oceanogr 39:12-20

Reinfelder JR, Wang WX, Luoma SN, Fisher NS (1997) Assimilation efficiencies and turnover rates of trace elements in marine bivalves: a comparison of oysters, clams and mussels. Mar Biol 129:443-452

Riedel GF, Ferrier D, Sanders JG (1991) Uptake of selenium by fresh-water phytoplankton. Water Air Soil Pollut 57: 23-30

Riedel GF, Sanders JG, Gilmour CC (1996) Uptake, transformation, and impact of selenium in freshwater phytoplankton and bacterioplankton communities. Aquat Microb Ecol 11:43-51

Strathmann RR (1967) Estimating the organic carbon content of phytoplankton from cell volume or plasma volume. Limnol Oceanogr 12:411-418

Vandermeulen J, Foda A (1988) Cycling of selenite and selenate in marine-phytoplankton. Mar Biol 98:115-123

Wang WX, Fisher NS (1998) Accumulation of trace elements in a marine copepod. Limnol Oceanogr 43:273-283

Wang WX, Fisher NS (1999) Delineating metal accumulation pathways for aquatic invertebrates. Sci Total Environ 237/238:459-472

Wang WX, Fisher NS, Luoma SN (1996) Kinetic determinations of trace element bioaccumulation in the mussel Mytilus edulis. Mar Ecol Prog Ser 140:91-113

Wrench JJ (1978) Selenium metabolism in marine phytoplankters Tetraselmis tetrathele and Dunaliella minuta. Mar Biol 49:231-236

Wrench JJ, Measures CI (1982) Temporal variations in dissolved selenium in a coastal ecosystem. Nature 299: 431-433

Submitted: September 7, 2000; Accepted: December 8, 2000 Proofs received from author(s): March 7, 2001 